\title{
Articulating Resistance: Agonism, Radical Democracy and Climate Change Activism
}

\author{
William Kakenmaster ${ }^{\text {a }}$ \\ ${ }^{\text {a }}$ London School of Economics and Political Science
}

\begin{abstract}
This article analyses climate change activism through the framework of agonism. It discusses dominant political theories of climate change and then contrasts those with agonism. Next, it proceeds to analyse the logic of resistance in climate change activism, focusing on the 2017 People's Climate March (PCM17) to understand how it articulated both its conceptions of the political and of climate change. This article argues that, in articulating its logic of resistance, the PCM17 served to depoliticise climate change by embracing a consensus-based conception of the political and a singular conception of climate change. The PCM17's claim of resistance therefore constrained dissent and was ultimately counterproductive to a vibrant politics of climate change. Rather than understanding climate change as singular, I argue that reconsidering climate change as multiple - that is, as an unstable, contested representation of multiple political ecologies - provides the political space necessary to accommodate dissent in debate about climate change without abdicating the responsibility to acknowledge its existence as a political problem. An agonistic framework of climate change politics severs the tie between the political and consensus, allowing a radical democratic politics of climate change to adopt a robust logic of resistance in climate change activism.
\end{abstract}

\section{Keywords}

agonism, radical democracy, People's Climate March

'[C]onsensus... is, in a word, the disappearance of politics'. ${ }^{1}$

\section{Introduction}

Of all the claims made about climate change, one is especially peculiar. In 2013, after reviewing nearly 12,000 scientific papers, researchers mostly from Australia and North America concluded that 97 percent of scientists agree that human activity causes climate change. ${ }^{2}$ This, they claimed, demonstrated that a consensus on climate change had been reached, which could strengthen public policy. While neither a new or original contribution to the literature, the paper roared onto the scene of an already clamorous climate change debate. ${ }^{3}$ Almost overnight, its thunderous conclusions gained international stardom as media outlets around the world continually repeated the now infamous 97 percent figure. Many believed, as they still do, that debate about climate change had ended. It was in this context of an overwhelming belief in and desire for consensus that the first iteration of the People's Climate March took place.

\footnotetext{
${ }^{1}$ Jacques Rancière, Disagreement: Politics and Philosophy (Minneapolis: University of Minnesota Press, 1999), 102.

${ }^{2}$ John Cook et al., 'Quantifying the Consensus on Anthropogenic Global Warming in the Scientific

Literature', Environmental Research Letters 8, no. 2 (2013): 024024.

${ }^{3}$ Cf. Naomi Oreskes, 'The Scientific Consensus on Climate Change', Science 306, no. 5702 (2004): 1686; Peter Doran, and Maggie Kendall Zimmerman, 'Examining the Scientific Consensus on Climate Change', Eos 90, no. 3 (2009): 22-23; William R.L. Anderegg, James W. Prall, Jacob Harold, and Stephen H. Schneider, 'Expert Credibility in Climate Change', Proceedings of the National Academy of Sciences 107, no. 27 (2010): 12107-12109.
} 
On 21 September 2014, some 300,000 demonstrators took to the streets of New York City to advocate for greater action on climate change. Central to the message of the 2014 People's Climate March (PCM14) was the notion that a clear path to abating climate change existed but had simply been ignored. Thus, rather than oppose elites, who had presumably neglected climate change, the PCM14 joined them, marching alongside figures such as Al Gore and Ban Ki-moon. In a stunning and apparent contradiction, the PCM14 issued a 'demand' for action on climate change, but also an 'invitation' for political elites to receive that demand. ${ }^{4}$

By the time its second iteration unfolded, another peculiar phenomenon had taken place. Now part of a self-avowed People's Climate Movement, the 2017 People's Climate March (PCM17) turned to Washington, DC to demand that the Trump administration undertake efforts to reverse climate change. ${ }^{5}$ Like its predecessor, the PCM17 mobilised hundreds of thousands of supporters yet, unlike the PCM14, adopted a distinctly hardened tone. Whereas the PCM14 invited elites to adopt its demands, the PCM17 asserted itself as a defiant struggle against elite efforts to abrogate environmental regulations and dismantle governmental programmes to combat climate change. Signs reading, 'We Rise! We Build! We Resist!' came to replace those reading, 'Our Demands Are Not Radical'. Bill McKibben, a prominent environmentalist and the main organiser of both demonstrations, even characterised the task of the latter march as one of 'full-on resistance'. 6

Underneath this articulation of resistance and claims to have discovered a consensus on climate change lie contentious notions of climate change as a political problem and notions of the political themselves bristling with contestation. This article seeks to provide an introductory answer to the following questions: How did the PCM17 make sense of itself as part of a resistance movement? What assumptions did it adopt about the nature of the political and of climate change in articulating this logic of resistance? It does so by analysing the PCM17 using agonism, a political theory that embraces conflict, disagreement and dissent as central to politics. Ultimately, it argues, the PCM17's logic of resistance served to depoliticise climate change both by adopting a consensus-based conception of the political and a singular conception of climate change. Paradoxically, the PCM17's call to political action constrained dissent and was thoroughly depoliticising. Against this, this article argues that reconsidering the political as conflictual and climate change as multiple allows a radical democratic politics of climate change to flourish, instrumentalising a logic of resistance that accommodates dissent and acknowledges the existence of climate change.

\section{Taking Stock of the Conceptual Landscape of Climate Change Politics}

\footnotetext{
${ }^{4}$ Bill McKibben, 'A Call to Arms: An Invitation to Demand Action on Climate Change', Rolling Stone, 21 May 2014. Available at: https://www.rollingstone.com/politics/politics-news/a-call-to-arms-an-invitation-to-demandaction-on-climate-change-92885/. Last accessed April 3, 2019.

${ }^{5}$ It is worth noting that, by this time, the same team had again concluded that 97 percent of scientists agreed that human activity causes climate change. See John Cook et al., 'Consensus on Consensus: A Synthesis of Consensus Estimates on Human-Caused Global Warming', Environmental Research Letters 11, no. 4 (2016): 048002. The People's Climate Movement is now a full-fledged movement with activities across the United States and elsewhere. See https://peoplesclimate.org/. Last accessed April 3, 2019.

${ }^{6}$ Brady Dennis, 'How Is This Weekend's Climate March Different from Its Predecessor? "Now, the Task Is Full-On Resistance"', The Washington Post, 27 April 2017. Available at: https://www.washingtonpost.com/news/energyenvironment/wp/2017/04/27/how-is-this-weekends-climate-march-different-from-its-predecessor-now-the-task-isfull-on-resistance/. Last accessed April 3, 2019.
} 
Climate change raises numerous matters of contention for politics, and there are numerous ways to organise debate about them. ${ }^{7}$ This article follows the typology constructed by Machin and reconstructed elsewhere, in which there are four dominant approaches to the politics of climate change: the techno-economic, ethical-individualist, green republican and green deliberative schools of thought. ${ }^{8}$ It also necessarily distinguishes between politics and the political to interrogate the assumptions each school of thought makes about the political and then to analyse the PCM17. Following Mouffe, it conceptualises politics as the manifold ontic practices and institutions in political life, whereas the political refers to the ontological principles, structures and forces that give rise to such practices and institutions in the first place. ${ }^{9}$ Moreover, this article concurs with Mouffe that the political derives from relations of antagonism, which implies that politics ultimately depends on conflict, and discusses this in detail in the next section. ${ }^{10}$ Each of the four schools of thought below ostensibly differs in their understanding of the relationship between climate change, politics and activism. However, they all conceptualise the political in terms of consensus and therefore reject addressing climate change through politics.

The techno-economic approach to climate change embodies a range of ideas in science, technology and economics that seek to solve climate change by influencing people's behaviour as rational, self-interested, private individuals. Under this paradigm, properly structuring economic incentives and radically embracing science and technology stimulates both mitigation and adaptation activities. ${ }^{11}$ Advocates suggest economic policy mechanisms, such as carbon markets ${ }^{12}$ and resilience bonds, ${ }^{13}$ and scientific schemes such as geoengineering ${ }^{14}$ and carbon capture and sequestration, ${ }^{15}$ as having the most potential to deal with climate change. Activism takes the form of 'financial' or 'shareholder' activism, which aims to combat climate change

\footnotetext{
${ }^{7}$ See for e.g. Yves Pepermans and Pieter Maeseele, 'The Politicization of Climate Change: Problem or Solution?' WIREs Climate Change 7, no. 4 (2016): 478-485; Amanda Machin, Negotiating Climate Change: Radical Democracy and the Illusion of Consensus (London: Zed Books, 2013); Thomas Bernauer, 'Climate Change Politics', Annual Review of Political Science 16 (2013): 421-448; Loren R. Cass, 'The Politics of Climate Change', in Oxford Research Encyclopedia of International Studies, ed. Renée Marlin-Bennett (Oxford: Oxford University Press, 2017). Available at: http://oxfordre.com/internationalstudies/view/10.1093/acrefore/9780190846626.001.0001/acrefore9780190846626-e-112. Last accessed April 10, 2019.

${ }^{8}$ See Machin, Negotiating Climate Change; Pepermans and Maeseele, 'The Politicization of Climate Change'; Reed Kurtz, 'Climate Change and the Ecology of the Political: Moderate, Radical, and Marxist Perspectives on the Politics of Climate Change', (paper presented at the International Studies Association's 58th Annual Convention, Baltimore, MD, 22-25 February 2017).

${ }^{9}$ Chantal Mouffe, On the Political (Abingdon: Routledge, 2005), 8-9.

${ }^{10}$ Ibid., 9.

${ }^{11}$ Sarah Anderson et al., 'The Critical Role of Markets in Climate Change Adaptation', Economics Working Paper 18107 (Palo Alto: Hoover Institution, 2018); William Nordhaus, The Climate Casino: Risk, Uncertainty, and Economics for a Warming World (New Haven: Yale University Press, 2015); Nicholas Stern, The Economics of Climate Change: The Stern Review (Cambridge: Cambridge University Press, 2007).

12 Raphael Calel, 'Carbon Markets: A Historical Overview', WIREs Climate Change 4, no. 2 (2013): $107-119$.

${ }^{13}$ Andreas Horsch and Sylvia Richter, 'Climate Change Driving Financial Innovation: The Case of Green Bonds', Journal of Structured Finance 23, no. 1 (2017): 79-90.

${ }^{14}$ Juan B. Morenzo-Cruz and Sjak Smulders, 'Revisiting the Economics of Climate Change: The Role of Geoengineering', Research in Economics 71, no. 2 (2017): 212-224.

${ }^{15}$ Matthias Honegger and David Reiner, 'The Political Economy of Negative Emissions Technologies:

Consequences for International Policy Design', Climate Policy 18, no. 3 (2018): 306-321.
} 
through free-market capitalism. ${ }^{16}$ According to the techno-economic approach, climate change fundamentally represents a scientific problem, and just as science has revealed the causes of climate change, so too will it reveal solutions to it.

Here, politics retreats behind science, the latter functioning not only to understand the causal relationships underpinning climate change, but also to change them. This ontologically subordinate position of politics to science assumes consensus is necessary for resolving climate change, and that politics' role is to realise scientific conclusions in society. Consensus forms the basis of the political under this framework, with the politics of climate change stonewalled without agreement in science. Climate change also emerges as a problem with discrete causes, effects and solutions. Rising carbon dioxide concentrations, climbing temperatures, sea-level rise and more extreme weather patterns stem from a lack of scientific expertise and economic incentives. With the right corrective measures, the techno-economic approach claims to be able to reconfigure individuals' behaviour to reduce and reverse climate change. These measures abound in science, technology and economics - politics need only draw on them in the technoeconomic ideal.

Ethical-individualists propose awakening people's moral and ethical obligations to combat climate change. Advanced by moral philosophers, theologians and scholar-activists, ethicalindividualism regards climate change as a moral issue that stems from a deeply unethical way of living. ${ }^{17}$ Furthermore, many ethical-individualists consider climate change a global problem that disregards political frontiers and national identities. ${ }^{18}$ Accordingly, addressing climate change depends on individuals behaving ethically, not just rationally, and managing climate change based on their common human identity. ${ }^{19}$ Climate change activism resembles a religious movement for many ethical-individualists insofar as it incorporates the 'severity of climate change and individual sacrifices through everyday moral choices' into people's belief systems. ${ }^{20}$

Politics, auxiliary to moral philosophy in this school of thought, provides space for ethics to flourish, but is not itself a means to address climate change. However, reorienting belief systems towards a more ethical view of climate change requires agreement about the moral value of the

\footnotetext{
${ }^{16}$ Michael MacLeod and Jacob Park, 'Financial Activism and Global Climate Change: The Rise of Investor-Driven Governance Networks', Global Environmental Politics 11, no. 2 (2011): 54-74; John Byrd and Elizabeth S.

Cooperman, 'Shareholder Activism for Stranded Asset Risk: An Analysis of Investor Reactions for Fossil Fuel Companies', International Review of Accounting, Banking, and Finance 9, no. 1 (2017): 185-202.

${ }^{17}$ Kevin J. O'Brien, The Violence of Climate Change: Lessons of Resistance from Nonviolent Activists (Washington: Georgetown University Press, 2017); Stephen M. Gardiner, A Perfect Moral Storm: The Ethical Tragedy of Climate Change (Oxford: Oxford University Press, 2013); Dale Jamieson, Reason in a Dark Time: Why the Struggle Against Climate Change Failed-And What it Means for Our Future (Oxford: Oxford University Press, 2014); Martin Schönfeld, 'Plan B: Global Ethics on Climate Change', Journal of Global Ethics 7, no. 2 (2011): 129-136.

${ }^{18}$ Paul G. Harris, World Ethics and Climate Change: From International to Global Justice(Edinburgh: Edinburgh University Press, 2010), 118.

${ }^{19}$ Adam Riggio, Ecology, Ethics, and the Future of Humanity (New York: Palgrave Macmillan, 2015); Harris, World Ethics and Climate Change, 118. See also, Paul G. Harris, Global Ethics and Climate Change, 2nd ed. (Edinburgh: Edinburgh University Press, 2016); Paul G. Harris and Jonathan Symons, 'Justice in Adaptation to Climate Change: Cosmopolitan Implications for International Institutions', Environmental Politics 19, no. 4 (2010): 617-636.

${ }^{20}$ Shonil A. Bhagwat, Anastasia Economou, and Thomas F. Thornton, 'The Idea of Climate Change as a Belief System: Why Climate Activism Resembles a Religious Movement', GAIA: Ecological Perspectives for Science and Society 25, no. 2 (2016): 94.
} 
environment, how much weight it deserves and what ethical solutions to climate change are. Ethical-individualism folds these questions into its conception of the political, which assumes to overcome disagreement about climate change by inspiring belief in the moral imperative to solve it. Some ethical-individualists acknowledge the scientific, environmental, human, political, economic, religious and other dimensions of climate change, referring to it as a 'wicked problem'. ${ }^{21}$ However, since this approach assumes politics derives purpose from ethics, the 'wicked problem' of climate change follows from the conception of climate change as a symptom of unethical living. Ultimately, moral consciousness and an awareness of people's commitment to others form the basis of the ethical-individualist approach to climate change.

The third school of thought, green republicanism, prioritises addressing climate change in public life. Given the intensely public nature of climate change, green republicans advocate for solving climate change in communities and, importantly, citizenries. ${ }^{22}$ For green republicans, the values of environmentalism, such as caring for the commons, dovetail with rights' derivative status relative to responsibilities and republican values, such as civic duty and republican virtue. ${ }^{23}$ Moreover, citizens' environmental duties stem from their ecological stewardship in society rather than from consumption, as in the techno-economic approach, or from ethics, as for ethicalindividualists. Ecological stewardship, situated within civic participation, leads green republicans to propose ideas such as maintaining community green spaces or participating in state-sponsored sustainability programmes. ${ }^{24}$ Relatedly, this approach sees political protest as a distinctive expression of climate change activism, which it argues resonates with those who might not understand or accept green policies. ${ }^{25}$ Halting climate change is, in this view, fundamentally part of people's duty as citizens.

Although green republicans appear to support political responses to climate change, they nevertheless assume consensus to be necessary for managing climate change in the politics they envision. The claim that the responsibility needed to combat climate change can be found in citizens acting in 'the common good' depends on an accepted understanding of the common good. Yet, even among green republicans, multiple ideas - sometimes in stark contradiction with one another - exist about the civic virtues that foster a climate-friendly society and the

${ }^{21}$ O'Brien, The Violence of Climate Change, 18.

22 John Barry, 'Towards a Green Republicanism: Constitutionalism, Political Economy, and the Green State', The Good Society 17, no. 2 (2008): 1-12; Hope M. Babcock, 'Civic Republicanism Provides Theoretical Support for Making Individuals More Environmentally Responsible', Notre Dame Journal of Law, Ethics, and Public Policy 23, no. 2 (2009): 515-536; Peter Cannavò, 'Environmental Political Theory and Republicanism', in The Oxford Handbook of Environmental Political Theory, eds. Teena Gabrielson et al. (Oxford: Oxford University Press, 2016). Available at: http://www.oxfordhandbooks.com/view/10.1093/oxfordhb/9780199685271.001.0001/oxfordhb9780199685271-e-20. Last accessed April 10, 2019.

${ }^{23}$ John Barry, The Politics of Actually Existing Unsustainability: Human Flourishing in a Climate-Changed, Carbon Constrained World (Oxford: Oxford University Press, 2012); Peter Cannavò, 'Ecological Citizenship, Time, and Corruption: Aldo Leopold's Green Republicanism', Environmental Politics 21, no. 6 (2012): 864-881; Ashley Dodsworth, 'Republican Environmental Rights' (paper presented at the European Consortium for Political Research 2018 Joint Sessions of Workshops, University of Nicosia, Cyprus, April 10-14, 2018); Derek Wall, 'Green Politics and the Republican Commons', Community Development Journal 49, no. S1 (2014): i81-i91.

${ }^{24}$ Barry, The Politics of Actually Existing Unsustainability.

25 Jinny A. Turman, 'Green Civic Republicanism and Environmental Action against Surface Mining in Lincoln County, West Virginia, 1974-1990', The Journal of Southern History 82, no. 4 (2016): 856; Jinny A. Turman, 'The Catholic Workers and 'Green” Civic Republicanism in Lincoln County, WV: 1969-1979', Journal of Moral Theology 6, no. 1 (2017): 94-113. 
responsibilities that bring it into being. Thus, in the green republican approach, climate change poses a problem of merely discerning the correct alignment of republican and environmentalist precepts and then realising that alignment in society. Green republicanism ultimately renders politics possible only to the extent it achieves consensus.

The green deliberative approach, lastly, agrees that resolving climate change must take place in public life and considers democracy central to doing so. Green deliberatives oppose efforts to curb climate change through despotism, oppression and coercion. ${ }^{26}$ Instead, they argue, more inclusive debate about climate change and support for democracy can galvanise reluctant citizens to take climate change seriously and act on it. ${ }^{27}$ Conceptualising democracy in terms of an 'inclusive, competent and dispersed' global public sphere, green deliberatives suggest that deliberation leads citizens to hold only those views that pass muster in public debate - views they argue would support reversing climate change. ${ }^{28}$ Yet, public debate must truly comprise the public, and green deliberatives insist on free, equal and rational debate about climate change. Such debate also extends the boundaries of politics and grants legitimacy to climate change activists for this school of thought. ${ }^{29}$ The 'authentic deliberation' that results breaks down the socalled 'efficacy dilemma' and allows the sincerer but more radical views of climate change activists to be taken seriously. ${ }^{30}$ In other words, infusing the politics of climate change with the free, equal and rational components of deliberative democracy expands politics and renders activists' concerns legitimate.

The green deliberative approach begins to mark the outlines of an inclusive politics of climate change, which could accommodate dissent in public discourse. Yet, the need for agreement on the free, equal and rational terms of debate in the green deliberative approach assumes a neat and tidy meaning of each. To arrive at a conclusion about what free, equal and rational debate means, however, is to hegemonise the dominant conception of it. By eliding these relations of power in climate change politics, green deliberatives' assumption that agreement is not only necessary but desirable offers little reprieve from the consensus problematic in the other three schools of thought. Green deliberatives conceptualise the political in terms of aligning different views on climate change through debate. Solving climate change in politics thus arises as a matter of

\footnotetext{
${ }^{26}$ Steven Vanderheiden, Atmospheric Justice: A Political Theory of Climate Change (Oxford: Oxford University Press, 2008).

${ }^{27}$ Hayley Stevenson and John S. Dryzek, Democratizing Global Climate Governance(Cambridge: Cambridge University Press, 2014); Walter F. Baber and Robert V. Bartlett, Global Democracy and Sustainable Jurisprudence: Deliberative Environmental Law (Cambridge: MIT Press, 2009); Simon Niemeyer, 'Democracy and Climate Change: What Can Deliberative Democracy Contribute?', Australian Journal of Politics and History 59, no. 3 (2013): 429-448.

${ }^{28}$ Hayley Stevenson and John S. Dryzek, 'The Discursive Democratisation of Global Climate Governance', Environmental Politics 21, no. 2 (2012): 189.

${ }^{29}$ Julie Uldam and Tina Askanius, 'Online Civic Cultures: Debating Climate Change Activism on YouTube', International Journal of Communication 7 (2013): 1185-1204; Jennifer Dodge, 'Environmental Justice and Deliberative Democracy: How Social Change Organizations Respond to Power in the Deliberative System', Politics and Society 28, no. 3 (2009): 225-239; Shannon K. Orr, 'Institutional Control and Climate Change Activism at COP 21 in Paris', Global Environmental Politics 16, no. 3 (2016): 23-30.

${ }^{30}$ Markus Holdo, 'Sincerity as Strategy: Green Movements and the Problem of Reconciling Deliberative and Instrumental Action', Environmental Politics. Published online 29 March 2018. Available at: https://doi.org/10.1080/09644016.2018.1457294. Last accessed April 3, 2019.
} 
finding the 'right' rules for debate. Green deliberatives ultimately dismiss the potentially constructive role of conflict in politics and in constituting the political itself.

Of course, other perspectives than these exist. Critical perspectives on climate change comprise anarchist, ${ }^{31}$ Marxist, ${ }^{32}$ radical feminist ${ }^{33}$ and other approaches. Debate about climate change in Politics and International Relations is beginning to acknowledge that dealing with climate change 'will necessarily involve agonism and conflict' in any renewed focus on the political, even while scholars disagree about the implications this would entail. ${ }^{34}$ The agonistic shift that is beginning to occur, however, is set against the background of the above four approaches, each of which represents a dominant perspective on climate change politics and conceptualises the political as based on consensus. Importantly, this shift has also revived interest in agonism and conflict in the politics of climate change.

\section{An Agonistic Framework of Climate Change}

An agonistic framework of climate change begins from a markedly different position than dominant schools of thought. Agonistic approaches to climate change argue that consensus is neither possible nor desirable, and instead consider dissent central to the conflictual relations of power that constitute the political and make any politics of climate change possible. Furthermore, agonists reject the strict rationalism of many other schools of thought, also rejecting a politics based on enmity. Taken together, an agonistic framework of climate change abandons the idea of consensus, rejects a rationalist ontology and conceives of competition in adversarial but not acrimonious terms. This section outlines the framework of agonism used to analyse the PCM17. ${ }^{35}$

First, agonism views consensus as an empirical illusion. Machin, for example, argues that achieving consensus on climate change is impossible because climate change 'is a parallax... that cannot ever be directly observed but is seen from a multiplicity and diversity of standpoints'. ${ }^{36}$ In this view, multiple observations of climate change are indirect and incommensurable, which Machin claims likely explains the lack of political action on climate change. ${ }^{37}$ In a similar vein, Hulme argues that climate change 'carries quite different meanings and... courses of action' depending on competitive differences in attitudes to risk, technology,

\footnotetext{
31 Alan Carter, A Radical Green Political Theory (New York: Routledge, 2013).

${ }^{32}$ Kurtz, 'Climate Change and the Ecology of the Political'.

${ }^{33}$ Sherilyn MacGregor, 'Only Resist: Feminist Ecological Citizenship and the Post-politics of Climate Change', Hypatia 29, no. 3 (2014): 617-633; Cara Daggett, 'Petro-masculinity: Fossil Fuels and Authoritarian Desire', Millennium: Journal of International Studies 47, no. 1 (2018): 25-44.

${ }^{34}$ Anthony Burke et al., 'Planet Politics: A Manifesto from the End of IR', Millennium: Journal of International Studies 44, no. 3 (2016), 507; cf. David Chandler et al., 'Anthropocene, Capitalocene and Liberal Cosmopolitan IR: A Response to Burke et al.'s "Planet Politics"', Millennium: Journal of International Studies 46, no. 2 (2018): 190208; Stefanie Fishel et al., 'Defending Planet Politics', Millennium: Journal of International Studies 46, no. 2 (2018): 209-219.

${ }^{35}$ Not all those cited in this section would necessarily identify their work as agonist in the manner of Mouffe. However, they are included here because their work either draws heavily on Mouffe's work (Hulme) or focuses on many of the same concepts, such as consensus and the political (Swyngedouw).

${ }^{36}$ Machin, Negotiating Climate Change, 88.

37 Ibid.
} 
ethics, ideology, politics and time. ${ }^{38}$ '[F]acts', Hulme also claims, 'do not speak for themselves'. ${ }^{39}$ Acting politically requires ascribing socially significant meanings to the facts and science at stake in the case of climate change. Agonists like Connolly might claim that there is no obvious distinction between describing a political problem like climate change and acting politically given the evaluative vocabularies of politics. Climate change in this view represents an essentially contested concept, which is impossible to define or analyse as a political problem without an implicit judgment of it based on value-laden political languages that inherently create multiple, conflicting interpretations. ${ }^{40}$ Moreover, because the meanings of facts differ based on 'different contexts, places and networks', they inevitably produce 'multiple and conflicting' political responses to climate change. ${ }^{41}$ As Machin observes, 'Consensus on how to combat climate change cannot and will not ever be reached' because climate change, as a multifaceted, kaleidoscopic idea constructed through competitive meaning-making processes, is a 'culturally mediated and politically contested' idea. ${ }^{42}$ Agonists also claim, however, that consensus on climate change is not only impossible but undesirable.

Agonism views consensus as undesirable because it suppresses dissent and embodies a rejection of the political. Building on two tenets of Mouffe's agonistic pluralism - conflictual consensus and hegemony - agonistic theories of climate change disavow efforts to establish consensus. ${ }^{43}$ Mouffe embraces disagreement and conflict as inherent to politics in modern, pluralist democracies. ${ }^{44}$ Although she concedes that some agreement is needed to constitute the 'ethicopolitical principles' of pluralist democracy, Mouffe argues that since those principles 'can only exist through many different and conflicting interpretations of them, such a consensus is bound to be a "conflictual consensus". ${ }^{45}$ Similarly, because the political arises from relations of antagonism based on power, consensus does not merely suggest agreement but is also an expression of hegemony, which subordinates some political identities to others through discourse. Mouffe writes, 'Consensus in a liberal-democratic society is - and will always be the expression of a hegemony and the crystallization of power relations' ${ }^{46}$ Connolly, in even stronger terms, condemns consensus: 'It is not just that I think full consensus is unrealizable, I think the attempt to realize it is always a form of tyranny' ${ }^{47}$ Finally, Machin argues that attempts to dispel disagreement represent attempts to eradicate politics, since 'decision is underpinned not by consensus but by disagreement, for without a choice between real alternatives there can be no

\footnotetext{
${ }^{38}$ Mike Hulme, Why We Disagree About Climate Change: Understanding Controversy, Inaction, and Opportunity (Cambridge: Cambridge University Press, 2009), xxv-xxvi.

${ }^{39}$ Mike Hulme, '(Still) Disagreeing About Climate Change: Which Way Forward?', Zygon 50, no. 4 (2015): 893.

${ }^{40}$ William E. Connolly, The Terms of Political Discourse (Princeton: Princeton University Press, 1983).

${ }^{41}$ Hulme, '(Still) Disagreeing About Climate Change', 893-4.

${ }^{42}$ Machin, Negotiating Climate Change, 5; Mike Hulme, 'Why We Should Disagree about Climate Change', in Climate Change and Museum Futures, eds. Fiona Cameron and Brett Neilson (New York: Routledge, 2015 ), 11.

${ }^{43}$ Chantal Mouffe, The Democratic Paradox (London: Verso, 2000).

${ }^{44}$ Chantal Mouffe, The Return of the Political (London: Verso, 1993), 2; Mouffe, The Democratic Paradox, 14-15; Mouffe, On the Political, 4.

${ }^{45}$ Mouffe, The Democratic Paradox, 103.

46 Ibid., 49.

${ }^{47}$ William E. Connolly, Neuropolitics: Thinking, Culture, Speed (Minneapolis: University of Minnesota Press, 2002), 244.
} 
decision' ${ }^{48}$ Since conflict is ineradicable, attempts to establish consensus on climate change marginalise dissent and undermine the constitutive role of disagreement in politics. ${ }^{49}$ Without such conflict, there can be no politics of climate change according to agonism, making consensus impossible and antithetical to the political.

Related to agonism's conflictual conception of the political, some scholars claim that dominant approaches to climate change indicate a 'post-political' condition. ${ }^{50}$ This, they suggest,

forecloses (or at least attempts to do so) politicization and evacuates dissent through the formation of a particular regime of environmental governance that revolves around consensus, agreement, participatory negotiation of different interests and technocratic expert management in the context of a non-disputed management of market-based socioeconomic organization. ${ }^{51}$

Nevertheless, interpretations of the ways in which post-political discourses of climate change attempt to forge consensus differ. Swyngedouw argues that apocalyptic narratives of climate change produce 'a thoroughly depoliticized imaginary' by juxtaposing a supposedly homogenous victim (humanity) with a supposedly hostile aggressor (nature). ${ }^{52}$ Such apocalyptic narratives of climate change routinely invoke 'the spectre of ecological annihilation' to 'cut across the idiosyncrasies of often antagonistic human and non-human "natures," silence "ideological and other constitutive social differences and disavow democratic conflicts about different possible socio-ecological configurations' ${ }^{53}$ For Hulme, the main consensualising force in post-political discourses of climate change is their description of climate change as a purely scientific problem necessitating a purely scientific solution. Hulme argues, 'Aggrandizing projects of Earth System Governance or climate engineering or a global carbon market are nothing short of political megaprojects, justified by some in the name of science as essential and nonnegotiable'. ${ }^{54}$ Extirpating dissent in debate about climate change, Hulme claims, inaugurates a 'brave new world' of 'tyranny and the mighty power of naturalism [that suppresses] the creative and legitimate tension of agonistic human beings'. ${ }^{55}$ Though consensus on climate change may materialise differently for different theorists, it is neither possible nor desirable according to an agonistic framework.

Agonistic theories of climate change also repudiate a strict rationalism. From an initial standpoint, agonists argue that a rationalist ontology oversimplifies political thought. Connolly,

\footnotetext{
${ }^{48}$ Machin, Negotiating Climate Change, 89; Amanda Machin, 'Decisions, Disagreement and Responsibility: Towards an Agonistic Green Citizenship', Environmental Politics 21, no. 6 (2012): 847; cf. Mouffe, On the Political, 3.

${ }^{49}$ Machin, Negotiating Climate Change, 2.

${ }^{50}$ Erik Swyngedouw, 'Climate Change as Post-Political and Post-Democratic Populism' (paper presented at DVPW conference, Kiel, Germany, September 22-5, 2009); Erik Swyngedouw, 'Apocalypse Forever? Post-Political Populism and the Spectre of Climate Change', Theory, Culture \& Society 27, no. 2-3 (2010): 213-232; Phillip Hammond, Climate Change and Post-Political Communication: Media, Emotion and Environmental Advocacy (London: Routledge, 2018).

${ }^{51}$ Swyngedouw, 'Apocalypse Forever?', 227.

52 Ibid., 227; Erik Swyngedouw, 'Depoliticized Environments: The End of Nature, Climate Change and the PostPolitical Condition', Royal Institute of Philosophy Supplement 69 (2011): 263.

53 Swyngedouw, 'Apocalypse Forever?', 217; Swyngedouw, 'Depoliticized Environments', 268.

${ }^{54}$ Hulme, 'Why We Should Disagree about Climate Change', 12.

55 Ibid., 12.
} 
for instance, argues that thought consists of both cognition and affect, the latter of which rationalism dismisses entirely. ${ }^{56}$ In Mouffe's terms, under a rationalist ontology, 'Passions are erased from the realm of politics, which is reduced to a neutral field of competing interests'. ${ }^{57}$ Tully questions the very foundations of rationality, rejecting both justification and interpretation as grounds for critical reflection and instead claiming that rationality depends on more than simply the many 'humdrum ways of acting with words' in political life. ${ }^{58}$ In addition to critiquing this 'universal canon of rationality', which reduces thought to cognitive self-interest, agonists argue that a rationalist ontology is politically dangerous. ${ }^{59}$ For Mouffe, the danger of a rationalist ontology of the political lies in its ability to disqualify dissent as 'either unreasonable or irrational' based on rationalism's own prior assumptions. ${ }^{60}$ Applied to the politics of climate change, Machin argues that 'rational discussion is rather a trick of power that disguises exclusion and inequality' by valorising a particular, narrow conception of the rational. ${ }^{61}$ Hulme similarly argues that a rationalist ontology negates the 'multifarious human beliefs, values, attitudes, and behaviours' at play in the construction of climate change as a political problem. ${ }^{62}$ The rationalism that permeates dominant approaches to climate change thus seeks to extinguish alternative ontologies by casting them as illegitimate violations of an assumedly essential condition of politics rather than engaging those ontologies in earnest.

As much as agonistic theories of climate change problematise the formulation of consensus under a rationalist ontology, they also devote significant focus to relational identities and adversarial competition. While conflict must exist in politics - particularly in pluralist democracy - enmity need not. Crucially, Mouffe distinguishes between

antagonism proper - which takes place between enemies, that is, persons who have no common symbolic space - and what I call "agonism", which is a different mode of manifestation of antagonism because it involves a relation not between enemies but between "adversaries", adversaries being defined in a paradoxical way as "friendly enemies", that is, persons who are friends because they share a common symbolic space but also enemies because they want to organize this common symbolic space in a different way. ${ }^{63}$

This inside/outside dichotomy - sometimes referred to as a 'we/they' distinction in Mouffe's work - enables the formation of political identities based on their constitutive outsides. ${ }^{64}$ Yet, given that the formation of political identities necessitates such inside/outside dichotomies, which Mouffe claims are impossible to overcome, the task of agonism becomes one of transforming antagonism 'so as to make available a form of we/they opposition compatible with

\footnotetext{
${ }^{56}$ Connolly, Neuropolitics.

${ }^{57}$ Chantal Mouffe, 'Democracy and Pluralism: A Critique of the Rationalist Approach', Cardozo Law Review 16 (1994/1995): 1543.

58 James Tully, 'Wittgenstein and Political Philosophy: Understanding Practices of Critical Reflection', Political

Theory 17, no. 2 (1989): 199.

${ }^{59}$ Mouffe, On the Political, 74.

${ }^{60}$ Ibid., 143; Mouffe, 'Democracy and Pluralism', 1541.

${ }^{61}$ Machin, Negotiating Climate Change, 5.

${ }^{62}$ Hulme, Why We Disagree About Climate Change, xxvi.

${ }^{63}$ Mouffe, The Democratic Paradox, 13.

${ }^{64}$ Mouffe, On the Political, 14.
} 
pluralist democracy' ${ }^{65}$ Mouffe's answer to such a transformation is to define conflict in adversarial terms. While an adversary is still an enemy, it is a legitimate one for whom agonists hold great respect. Understanding those with different views on climate change than oneself as 'respected adversaries, not enemies we need to vanquish' reinforces 'that all pursuits toward facts and truth are necessarily contested', including one's own. ${ }^{66}$ Furthermore, adversarial competition sanctions disagreement in the politics of climate change and actually allows for debate about the "aspects of climate change that really matter, which are not "is the world warming?" or "are humans causing it?", but rather the "values and... the forms of political organization and representation' needed for bringing about radical socio-ecological change. ${ }^{67}$ Nevertheless, the forms of conflict envisioned as undergirding the political differ between different theorists. Connolly and Mouffe, for instance, would likely agree that conflict institutes the political, but they would likely disagree on the forms of conflict that play more or less constructive roles in politics. For Mouffe, agonism implies the need for political contestation between opponents, while for Connolly it implies the need for an ethos of pluralisation, wherein new modes of difference emerge in reworked contexts of collaboration and collective action. ${ }^{68}$ Having a politics of climate change nevertheless depends on conflict for agonists, but this conflict need not take place between enemies.

Against consensus, against rationalism and against enmity, several scholars look forward to a radical democratic politics of climate change founded on the celebration of pluralist democracy. It is important to recognise that agonism is distinct from radical democracy. Scholars such as Mouffe and Machin endorse both agonism and radical democracy, though not always as necessarily related. Others' ideas, such as Connolly's ethos of pluralisation and Tully's Gaia citizenship, are much less opposed to green deliberative approaches to climate change, and might therefore not support radical democracy in any form. For agonists who are also radical democrats, however, embracing pluralism as 'an axiological principle... [to] celebrate and enhance' represents the first step in a radical democratic politics of climate change. ${ }^{69}$ Whereas capturing inside/outside dichotomies as relations between enemies threatens an 'eruption of antagonism... that shifts from the political realm towards moral territory', celebrating difference 'produces a more inclusive, insightful, and interesting politics' of climate change. ${ }^{70}$ Moreover, accommodating dissent avoids an overly narrow debate that oscillates between two seemingly dichotomous choices: accept or reject the supposed consensus on climate change.

Given that the political is forged in the crucible of societal relations of power for agonists, a radical democratic praxis of climate change could take multiple forms of counter-hegemony. ${ }^{71}$ Laclau and Mouffe advocate for 'chains of equivalence', where traditionally marginalised groups

\footnotetext{
65 Ibid., 19.

66 James S. Damico, Alexandra Panos, and Mark Baildon, "I'm Not in the Truth Business": The Politics of Climate Change with Pre-Service Teachers', English Teaching: Practice \& Critique 17, no. 2 (2018): 72.

${ }^{67}$ Hulme, 'Why We Should Disagree about Climate Change', 14.

${ }^{68}$ William E. Connolly, The Ethos of Pluralization (Minneapolis, MN: University of Minnesota Press, 1995); William E. Connolly, 'Rethinking the Ethos of Pluralization', Philosophy \& Social Criticism 24, no. 1 (1998): $93-$ 102; cf. Mouffe, The Democratic Paradox.

${ }^{69}$ Mouffe, The Democratic Paradox, 19.

${ }^{70}$ Machin, Negotiating Climate Change, 97-8.

${ }^{71}$ Ernesto Laclau and Chantal Mouffe, Hegemony and Socialist Strategy: Towards a Radical Democratic Politics, 2nd ed. (London: Verso, 2001).
} 
seeking radical change ally behind their common opposition to hegemony while retaining distinct political identities expressed through a differential logic. ${ }^{72}$ For Swyngedouw, combatting hegemonic imaginaries of climate change depends on politicising the environment, exploring multiple possible futures and constructing a socio-ecological counter-hegemony where the multiple natures at stake in political debate about climate change are not considered apart from humanity but rather inseparable from it. ${ }^{73}$ For Hulme, counter-hegemony means 're-animating religious myths and stories which can expand cultural repertoires - finding new stories through which to "pass judgment" on the facts of climate change'. ${ }^{74}$ Moreover, radical democratic agonists view activist strategies such as direct action not as mutually exclusive of discursive strategies of counter-hegemony, but rather as expressions of them. ${ }^{75}$ As such, sit-ins, blockades and occupations emerge within 'a process of hegemonic struggle' that seeks to dislocate prevailing narratives of climate change from their current strains of individualism and rationalism as much as it seeks progress in abating climate change. ${ }^{76}$ To the extent that such activist strategies enact 'a range of subject positions that identify themselves as antithetical to one another' and therefore enemies, they constitute antagonistic activist strategies. ${ }^{77}$ Some, such as Fougère and Bond, claim these antagonistic strategies create the preconditions for future relations of agonism. ${ }^{78}$ Nevertheless, for scholars who endorse radical democracy and agonism, combatting climate change is fundamentally a competitive political process opposed to hegemony.

An agonistic framework of climate change opposes dominant schools of thought in several ways. First, agonism views conflict as ineradicable and constitutive of the political, and relatedly views consensus as a rejection of the political. Second, agonism opposes a rationalist ontology, which it argues oversimplifies thought and dangerously polices dissent. Third, agonism reconceptualises inside/outside dichotomies in political debate about climate change as contests between adversaries, not enemies. With this, many agonists advocate for a radical democratic politics in which counter-hegemonies articulate alternative conceptions of climate change as an open, contested political problem.

\section{Articulating Resistance in the PCM17: Notions of the Political and Climate Change} In addition to dominant and agonistic theories of climate change, there exists an expansive literature on climate change activism. Scholars of climate change activism have interrogated

\footnotetext{
72 Ibid., 127.

${ }^{73}$ Erik Swyngedouw, 'Depoliticized Environments and the Promise of the Anthropocene', in International Handbook of Political Ecology, ed. Raymond L. Bryant (London: Edward Elgar Publishing, 2015), $131-145$.

${ }^{74}$ Hulme, '(Still) Disagreeing About Climate Change', 901.

${ }^{75}$ Callum McGregor, 'Cultural Politics of Climate Change Activism in the UK as Public Pedagogy (2005-2011): Direct Action, Relocalisation, and Professional Activism' (PhD diss., University of Edinburgh, 2014); Callum McGregor, 'Direct Climate Action as Public Pedagogy: The Cultural Politics of the Camp for Climate Action', Environmental Politics 24, no. 3 (2015): 343-362; Lillian Fougère and Sophie Bond, 'Legitimising Activism in Democracy: A Place for Antagonism in Environmental Governance', Planning Theory 17, no. 2 (2018): 144-5.

76 McGregor, 'Direct Climate Action as Public Pedagogy', 358.

${ }^{77}$ Fougère and Bond, 'Legitimising Activism in Democracy', 145.

78 Ibid.
} 
topics such as internet activism, ${ }^{79}$ art, affect and rhetoric, ${ }^{80}$ political beliefs and norms ${ }^{81}$ and social movement structures. ${ }^{82}$ However, the purpose of analysing the PCM17's logic of resistance through the perspective of agonism renders only a small subset of that literature apposite for this article. This section uses the People's Climate Movement's photographical records, as well as secondary texts, to reconstruct the PCM17's discourse and understand how its logic of resistance was organised with respect to notions of the political and climate change. It focuses principally on visual texts, such as protest signs, over written texts, such as blog posts, for two reasons. First, visual texts often combine verbal and non-verbal signifiers in ways that written texts cannot, producing layered discursive networks with a rich level of detail and complex systems of meaning. Second, whereas many of the written texts produced during the PCM17 no longer exist or are no longer widely accessible online, the People's Climate Movement maintains a database of photos from the PCM17, which means there are more texts to analyse.

The PCM17 was neither homogenous nor monolithic. Whether linked to an idea of resistance or not, the PCM17's discourse varied according to the particular spatial, temporal, historical, political, economic and social contexts within which it was uttered. Nevertheless, interpreting instances where it appealed to resistance through an agonistic frame of analysis can generate important insights for the study of climate change, politics and activism. Using the agonistic framework above, this section argues that the PCM17 served to depoliticise climate change by mobilising on a consensus-based conception of the political and a singular conception of climate change. Paradoxically, these two ideas composed a logic of resistance opposed to dissent rather than hegemony.

Ostensibly, the PCM17's motivation was to advance the PCM14's goals. However, it complicated this in claiming to resist the Trump administration's regressive policies on climate change and the environment. This logic of resistance rested on apparently complementary justifications in science, history, justice and spirituality that implicitly linked the PCM17's conception of the political to ideas of consensus. Indeed, the PCM17 frequently invoked the

\footnotetext{
${ }^{79}$ Jessica Emma McLean and Sara Fuller, 'Action With(out) Activism: Understanding Digital Climate Change Action', International Journal of Sociology and Social Policy 36, no. 9/10 (2016): 578-595; Kjerstin Thorson et al., 'Seeking Visibility in a Big Tent: Digital Communication and the People's Climate March', International Journal of Communication 10 (2016): 4784-4806; Uldam and Askanius, 'Online Civic Cultures', 1185-1204.

${ }^{80}$ Brian Cozen, 'Mobilizing Artists: Green Patriot Posters, Visual Metaphors, and Climate Change Activism', Environmental Communication 7, no. 2 (2013): 297-314; Nicholas S. Paliewicz, 'Making Sense of the People's Climate March: Towards an Aesthetic Approach to the Rhetoric of Social Protest', Western Journal of Communication 83, no. 1 (2018): 94-112; Amy Luers, 'Rethinking US Climate Advocacy', Climatic Change 120 (2013): 13-19.

${ }^{81}$ Connie Roser-Renouf et al., 'The Genesis of Climate Change Activism: From Key Beliefs to Political Action', Climatic Change 125 (2014): 163-178; Jean Léon Boucher, 'The Logics of Frugality: Reproducing Tastes of Necessity among Affluent Climate Change Activists', Energy Research \& Social Science 31 (2017): 223-232.

${ }^{82}$ Doug McAdam, 'Social Movement Theory and the Prospects for Climate Change Activism in the United States', American Political Science Review 20 (2017): 189-208; Jennifer Hadden, 'Explaining Variation in Transnational Climate Change Activism: The Role of Inter-Movement Spillover', Global Environmental Politics 14, no. 2 (2014): 7-25; Dana R. Fisher, 'Climate of Resistance: How the Climate Movement Connected to the Resistance', in The Resistance: The Dawn of the Anti-Trump Opposition Movement, eds. David S. Meyer and Sidney Tarrow (Oxford: Oxford University Press, 2018). Available at: http://www.oxfordscholarship.com/view/10.1093/oso/9780190886172.001.0001/oso-9780190886172-chapter-6. Last accessed April 10, 2019.
} 
notion that politics ought to replicate the consensus on climate change. Yet, conceptualising the political in terms of consensus, as the PCM17 did in elaborating its logic of resistance, suppressed dissent and fomented antagonistic relations of political identities.

By predicating its logic of resistance on opposition to the Trump administration, the PCM17 defined the distinction between itself and the administration as one principally of belief in or denial of climate change. Protest signs that read, 'Resist fossil fuels', accompanied effigies of Donald Trump and Trump administration officials to compose a clear portrait of the target of the PCM17's resistance. ${ }^{83}$ The PCM17 also directly countered the Trump administration's denial of climate change in repeated refrains that 'It's not a hoax!', referencing one of Trump's viral tweets. ${ }^{84}$ Moreover, this relationship framed acceptance of the scientific consensus on climate change in life-or-death terms through texts claiming 'climate change denial facilitates mass murder' and 'science saves lives'. ${ }^{85}$ These texts concretised the relationship between climate change politics and consensus as one not only of fact but moral imperative as well.

The PCM17's logic of resistance positioned itself as opposing Trump administration policies, and also as arranged around a layered discursive network that drew on science, history, justice and spirituality. Examples of this network populated texts' verbal and non-verbal symbols. For instance, chalkboards with graphs of carbon dioxide emissions, ${ }^{86}$ portraits of historically significant environmental activists, ${ }^{87}$ arrows in the 'CO2LONIALISM' wagon ${ }^{88}$ and a weeping Mother Earth ${ }^{89}$ accompanied protest signs reading, 'Policy without science is like Cheetos

${ }^{83}$ Julia DeSantis, 'Peoples Climate March - DC', Flickr, 29 April 2017. Available at: www.flickr.com/photos/peoplesclimatemarch/34322308126/in/album-72157683199634655/. Last accessed April 3, 2019; Sabelo Narasimhan, 'PCM 2017', Flickr, 29 April 2017. Available

at: www.flickr.com/photos/peoplesclimatemarch/34340971695/in/album-72157683199634655/. Last accessed April 3, 2019; Marcie Meditch, 'Washington DC People's Climate March Photos', Flickr, 29 April 2017. Available at: www.flickr.com/photos/peoplesclimatemarch/33553611883/in/album-72157683199634655/. Last accessed April 3, 2019.

${ }^{84}$ Bora Chung, 'People's Climate Rally in Washington, DC', Flickr, 29 April 2017. Available at: www.flickr.com/photos/peoplesclimatemarch/34309185346/in/album-72157683199634655/. Last accessed April 3, 2019; Donald Trump, Twitter, 6 December 2013, 7:13 AM. Available at: https://twitter.com/realDonaldTrump/status/408977616926830592. Last accessed April 3, 2019.

${ }^{85}$ Eliza Barclay and Brian Resnick, '10 of the Best Signs from the People's Climate March', Vox, 29 April 2017. Available at: www.vox.com/science-and-health/2017/4/29/15486370/peoples-climate-march-signs-live-stream. Last accessed April 3, 2019; Lacey Johnson and Ian Simpson, 'Environmental Protesters Swarm Outside White House as Trump Hits Milestone', Reuters, 29 April 2017. Available at: https://www.reuters.com/article/us-usa-trump-protestidUSKBN17V0B7. Last accessed April 3, 2019.

${ }^{86}$ Catherine Becker, 'A Tale of Two Marches', People's Climate Movement Blog, 14 May 2017. Available at: https://u.osu.edu/becker.271/tag/peoples-climate-movement/. Last accessed April 3, 2019.

${ }^{87}$ Kayla Epstein, 'The Artist Who Makes Giant Protest Signs of Famous Women Is Back for the Climate March.' The Washington Post, 28 April 2017. Available at: https://www.washingtonpost.com/news/energyenvironment/wp/2017/04/28/these-giant-protest-signs-of-famous-women-and-environmentalists-will-brighten-theclimate-march/. Last accessed April 3, 2019.

${ }^{88}$ Hector Emanuel, 'People's Climate March Washington DC 2017', Flickr, 29 April 2017. Available at: https://www.flickr.com/photos/peoplesclimatemarch/34213941451/in/album-72157683199634655/. Last accessed April 3, 2019.

${ }^{89}$ Eman Mohammed, 'Climate March', Flickr, 29 April 2017. Available at: https://www.flickr.com/photos/peoplesclimatemarch/34220614471/in/album-72157683199634655/. Last accessed April 3, 2019. 
without benzenesulphonic acid [sic]', 90 “"Facts are stubborn things" - John Adams, 1770', 91 'Climate justice is in our hands', 92 and 'Protect the sacred'. ${ }^{93}$ These themes variably countenanced the authorities of science, history, justice and spirituality to support calls to 'resist' and 'rise' against the Trump administration's anti-environmentalist actions. Moreover, the PCM17 appeared to give voice to many traditionally marginalised groups, including people of colour, indigenous people, women, young people, working class people and others, who together represented the 'builders of democracy'. ${ }^{94}$ Thus, it seemed the PCM17 offered the potential to enact a resistance movement that amalgamated techno-economic, ethical-individualist, green republican and green deliberative meanings to produce a diverse political response to climate change. In other words, it would appear the PCM17 had performed the ontological reality of climate change through a praxis that incorporated a range of approaches. ${ }^{95}$ Nevertheless, instantiating the PCM17's climate change resistance in this way assumed a consensus-based conception of the political. And, as Mol argues, the ontological multiplicity of politics implies a trade-off regarding the practices enacting it. ${ }^{96}$ In the case of the PCM17, enacting climate change through the lenses of science, history, justice and spirituality equivocated on the degree of conflict required in enabling the politics of climate change.

The four nodal points of science, history, justice and spirituality, combined with the dichotomisation of climate change belief and denial that established mutually exclusive political identities, mobilised a consensus-based conception of the political. Whether proclaiming ' $3 \%$ of scientists say this march doesn't exist' or 'Please think of the children', texts served to depoliticise climate change in two ways. ${ }^{97}$ First, they eliminated meaningful choice in the PCM17's politics and collapsed debate onto a matter of agreement with the rationales for reversing climate change as a manifestation of scientific, historical, normative or spiritual fact. To some degree, the PCM17's expanding of debate about climate change to encompass these four domains suggested that it acknowledged that 'disagreements about climate change... may

\footnotetext{
${ }^{90}$ Barclay and Resnick, '10 of the Best Signs'. Benzenesulfonic acid, often used as an artificial colourant in processed foods, gives Cheetos ${ }^{\circledR}$, a cheesy snack, their orange hue. This sign implies that policy without science is artificial, just as Cheetos ${ }^{\circledR}$ without their characteristic colouring are not really Cheetos ${ }^{\circledR}$.

${ }^{91}$ Johnson and Simpson, 'Environmental Protesters Swarm Outside White House',

92 Jocelyn Augustino, 'DC People's Climate March 2017', Flickr, 29 April 2017. Available at: https://www.flickr.com/photos/peoplesclimatemarch/33961618400/in/album-72157683199634655/. Last accessed April 3, 2019.

${ }^{93}$ Eman Mohammed, 'Climate March', Flickr, 29 April 2017. Available at: https://www.flickr.com/photos/peoplesclimatemarch/34220614471/in/album-72157683199634655/. Last accessed April 3, 2019.

94 Jocelyn Augustino, 'DC People’s Climate March 2017', Flickr, 29 April 2017. Available

at: https://www.flickr.com/photos/peoplesclimatemarch/34214672571/in/album-72157683199634655/. Last accessed April 3, 2019.

95 Annemarie Mol, 'Ontological Politics: A Word and Some Questions', The Sociological Review 47, no. S1 (1999): 74-89.

${ }^{96}$ Ibid.

${ }^{97}$ People's Climate, 'Untitled', Flickr, 29 April 2017. Available

at: https://www.flickr.com/photos/peoplesclimatemarch/33522432864/in/album-72157679974771404/. Last accessed April 3, 2019; Hector Emanuel, 'People's Climate March Washington DC 2017', Flickr, 29 April 2017. Available at: https://www.flickr.com/photos/peoplesclimatemarch/33503094694/in/album-72157683199634655/. Last accessed April 3, 2019.
} 
(and do) occur'. ${ }^{98}$ However, because the PCM17's practice of doing so took assumed relations between believers and deniers for granted, it left "the larger political questions about "how to live in the world" untouched' and out of bounds. ${ }^{99}$ Rather than a debate about the radical political changes needed to bring about an end to climate change, what emerged essentially consisted of a debate between two ostensibly dichotomous answers to the questions of whether climate change exists and whether humans cause it. In that sense, the narrowing of debate can be seen more properly as an exercise of hegemony by a status quo intensely resistant to change rather than a feat of politicisation. As Kenis argues, politicising climate change requires more than diversifying the 'nodal points' in activists' discourses. ${ }^{100}$ That is, it requires more than constructing climate change as a historical, normative and spiritual fact in addition to its construction as a scientific fact. It also requires that movements, demonstrations and activists themselves 'politicise their own stakes and goals', to acknowledge and embrace a conflictual form of politics in responding to climate change. ${ }^{101}$ Thus, in forwarding a consensus-based conception of the political, the PCM17 depoliticised climate change and adopted a logic of resistance not opposed to hegemonic narratives of it but as opposed to dissent. Debate about alternative forms of political organisation and ways of life underpinning effective redress for climate change was foreclosed in the PCM17; all that remained was consensus, oddly seated at both the starting and ending points of debate.

Some argue that, while the idea of a consensus-based politics may obfuscate exertions of hegemony by status quo powers, 'at least consensus implies that decisions get made'. ${ }^{102}$ However, with respect to climate change, decision depends on disagreement between proponents of meaningful choices rather than on consensus construed through pre-conceived frames of reference, such as the four nodal points in the PCM17's logic of resistance. Consensus 'does not underpin decision but rather precludes it by inhibiting political interaction... for without a choice between real alternatives there can be no decision' on addressing climate change as a political problem. ${ }^{103}$ The consensus inferred by the PCM17 thus alluded to a shared symbolic space of climate change, in the Mouffean sense, but little beyond that. Facts, whether of science, history, justice or spirituality, do not speak for themselves but are embedded within different spatial, temporal, political, economic and social contexts. Beyond just mitigating greenhouse gas emissions and adapting to climate change, consensus breaks down in these contexts. The logic of resistance articulated by the PCM17 therefore resembled 'a consensual aesthetic order' of the political but not one of radical change. ${ }^{104}$ The PCM17's consensus-based notion of the political thus foreclosed debate about climate change and depoliticised it. Paradoxically embracing a logic of resistance as one opposed to dissent, the PCM17 sought to remove climate change from politics by linking the political to consensus.

\footnotetext{
98 Peter Berglez and Ulrika Olausson, 'The Post-political Condition of Climate Change: An Ideology Approach', Capitalism Nature Socialism 25, no. 1 (2014): 54.

${ }^{99}$ Ibid., 54.

${ }^{100}$ Anneleen Kenis, 'Post-politics Contested: Why Multiple Voices on Climate Change Do Not Equal Politicisation', Environment and Planning C: Politics and Space (2018). Published online on 25 October. Available at: https://doi.org/10.1177/0263774X18807209.

${ }^{101}$ Kenis, 'Post-politics Contested', 4.

102 John S. Dryzek, 'Deliberative Democracy in Divided Societies: Alternatives to Agonism and Analgesia', Political Theory 33, no. 2 (2005): 221.

${ }^{103}$ Machin, Negotiating Climate Change, 101, emphasis added.

${ }^{104}$ Paliewicz, 'Making Sense of the People's Climate March', 2.
} 
Second, in contrast to its aim of achieving a radically inclusive protest, hierarchically constructed political identities in the PCM17's logic of resistance often dangerously captured inter-personal relations in moral terms. Operating within life-or-death considerations, and with debate restricted to a matter of agreement, alternative and critical conceptions of possible futures became relegated to secondary status, whereas relations between believers and deniers were brought to the fore. Signs that read, 'Water = life', 'Denied facts are still facts', 'Climate change denial facilitates mass murder' and 'Science saves lives', not only valorised consensus in constituting the political, they also contrived mutually exclusive political identities. ${ }^{105}$ Those who believed in climate change supported life while those who denied climate change supported death. The PCM17 sought to provide space for alternative political identities through what it called 'Circles of Resistance Art', where traditionally marginalised communities could share their collective understandings of climate change and visions for the future. ${ }^{106}$ And, to some degree, these could be read as forming 'chains of equivalence' - but not as Laclau and Mouffe understand them. According to Laclau and Mouffe, social actors 'occupy differential positions' in relation to one another but establish 'relations of equivalence between themselves' in relation to hegemony and, importantly, to counter prevailing power relations and resist hegemony. ${ }^{107}$ The PCM17's Circles of Resistance Art formed a chain not in opposition to hegemony, but rather in favour of it, suffering two important foibles.

On the one hand, alternative conceptions of political futures in these circles typified their expression as instances of agreement within the given communities. Claims that 'our existence is resistance' in these circles connoted a homogenous existence with an assumed degree of political salience for community members. ${ }^{108}$ On the other hand, their place within the broader category of 'believers' construed expressions of identity through the movement's prior system of identification rather than allowing it to operate outside of it. Underscoring supposedly hierarchical relations of identities, the PCM17 ultimately comprehended debate about climate change as taking place between those who believed in it and those who did not. In one and the same moment, for example, demonstrators combined symbols of resistance and indigenous identity with protest signs that read, 'No sides in climate'. ${ }^{109}$ The effect was to promote a logic of resistance wherein those resisting the Trump administration appeared to radically rethink possible combinations of political subjectivity, even while affirming hegemonic notions of belief in climate change as rote acceptance of non-negotiable science, history, justice or spirituality.

\footnotetext{
105 Hector Emanuel, 'People’s Climate March Washington DC 2017', Flickr, 29 April 2017. Available at: https://www.flickr.com/photos/peoplesclimatemarch/34213941451/in/album-72157683199634655/. Last accessed April 3, 2019; People's Climate, 'Climate Rally-35', Flickr, 30 April 2017. Available at: https://www.flickr.com/photos/peoplesclimatemarch/33539385283/in/album-72157683199634655/. Last accessed April 3, 2019; Johnson and Simpson, 'Environmental Protesters Swarm Outside White House'.

${ }^{106}$ Desiree Kane, 'Circles of Resistance Art at \#PCM2017', Flickr, 2017. Available at: https://www.flickr.com/photos/dbirdy/albums/72157681370528661. Last accessed April 3, 2019.

${ }^{107}$ Laclau and Mouffe, Hegemony and Socialist Strategy, xiii.

${ }^{108}$ Desiree Kane, 'Circles of Resistance Art at the Peoples Climate March 2017', Medium, 6 May 2017. Available at: https://medium.com/@DesireeKane/parachutes-at-the-peoples-climate-march-2017-ada3607d1bd3. Last accessed April 3, 2019; Kane, 'Circles of Resistance Art at \#PCM2017'.

${ }^{109}$ Eman Mohammed, 'Peoples Climate March 2017', Flickr, 29 April 2017. Available at: https://www.flickr.com/photos/peoplesclimatemarch/34343603195/in/album-72157683098482146/. Last accessed April 3, 2019.
} 
Capturing political identities in this way further served to remove climate change from politics. Paliewicz convincingly argues that the PCM14 provided the opportunity to consummate new political subjectivities in climate change activism but that the policing of space and mobility restrained possibilities for alternative, dissenting identities to flourish. ${ }^{110}$ Paliewicz rightly views this not as an instance of politics but of order and control. However, in the PCM17, political identities were not only policed by hegemonic conceptions of appropriate space and mobility, but also by the hierarchically situated relations between such identities themselves. Elsewhere, scholars have argued that the PCM14 used online communication to erect a 'very big tent' in 'a self-consciously inclusive' endeavour, but the boundaries of the 'tent' in the PCM17 were demarcated by the ordering of political identities vis-à-vis their relation to the movement's valorisation of consensus. ${ }^{111}$ Similarly, scholars have argued that the PCM17 composed 'intersectional interests that [crossed] racial identity, class, gender and sexuality', which enabled its logic of resistance and connected it to a broader resistance movement. ${ }^{112}$ Such intersectional interests seemingly coincided with the enactment of multiple ontologies of climate change politics. ${ }^{113}$ However, the PCM17 marshalled these interests in support of hegemony, both in the form of a consensus-based politics and a singular conception of climate change. It gave no quarter to critical conceptions of the political as debate was foreclosed and identity subsumed within hegemony.

In addition to its consensus-based conception of the political, the PCM17 conceptualised climate change as a singular problem. Demonstrators relied heavily on apocalyptic narratives of climate change that maintained it as a problem unparalleled in scope and magnitude. In protest slogans such as, 'There are no jobs on a dead planet', the PCM17 postured itself as resisting the Trump administration's anti-environmentalist policies, while also distilling climate change into a singular imaginary of total planetary destruction. ${ }^{114}$ However, this apocalyptic narrative also supported a depiction of climate change as a singular problem insofar as a fundamental overhaul of existing structures of political and economic power would eradicate its concomitant implications. This narrative of climate change frequently endorsed action on climate change but refrained from specifying the type of action needed. In conceiving of it as singular, the PCM17's logic of resistance paradoxically reproduced climate change as a stable yet chaotic phenomenon and hampered contestation over the values at stake in the construction of climate change as a political problem.

The PCM17's apocalyptic narrative foretold the death of Earth at the hands of climate change and lamented the lack of concerted effort that rendered the planet's death imminent. Symbols of a dead, barren planet populated protest signs, warning of the end of all life on Earth. ${ }^{115}$ The slogan, 'There is no Planet B', informed this apocalyptic imaginary by stoking what Davis calls

\footnotetext{
110 Paliewicz, 'Making Sense of the People's Climate March'.

111 Thorson et al., 'Seeking Visibility in a Big Tent', 4784.

112 Fisher, 'Climate of Resistance'.

${ }^{113}$ Cf. Mol, 'Ontological Politics'.

${ }^{114}$ Milan Rai, 'Editorial: Building Peace through Empowerment', Peace News, 8 March 2018. Available at: https://peacenews.info/node/8917/editorial-building-peace-through-empowerment. Last accessed April 3, 2019.

115 Ibid.; Ben Adler, 'Peoples Climate March Hits D.C. With New Goals for the Trump Era', Yahoo News, 30 April 2017. Available at: https://news.yahoo.com/peoples-climate-march-hits-d-c-new-goals-trump-era-000515727.html. Last accessed April 3, 2019.
} 
'ecologies of fear'. ${ }^{116}$ Indeed, the central motif of the PCM17's chronicle of planetary destruction, the point at which apocalypse and climate change collided, was the 'spectre of ecological annihilation'. ${ }^{117}$ Within the cacophonous, layered discursive network of the PCM17, climate change represented a singularity, a moment of pure cataclysm where human beings would confront the consequences of their actions only to find their utter destruction. Similarly, the actions from which climate change derived themselves suggested a singular cause: an inherently corrupt political and economic system in need of fundamental overhaul, as represented by effigies of Donald Trump and Scott Pruitt, as well as protest signs reading, 'Separate Oil \& State'. ${ }^{118}$ The problem of climate change here encompassed the height of disaster as well as the culmination of human error - it functioned as singular in its uniqueness and universality.

This singular conception of climate change depoliticised climate change through its construction as a threat of such sheer magnitude that a broken political and economic structure was incapable of solving it. Swyngedouw, citing Derrida, aptly describes the chaos warned of by this singular conception of climate change as 'not simply apocalypse now, but apocalypse forever... an apocalypse without apocalypse, an apocalypse without vision, without truth, without revelation... without message and without destination, without sender and without decidable addressee... an apocalypse beyond good and evil'. ${ }^{119}$ Similarly, Stehr and Machin argue, at the point of convergence between apocalypse and climate change, the distinction between stability and instability within the climate system itself is no longer clear. The climate 'is taken for granted as a steady background condition', while 'extreme weather events' paradoxically affirm the new normal with the reliability of catastrophic climate change being taken for granted. ${ }^{120}$ Yet, the implications of conceiving of climate change as a singular, aberrant phenomenon contradicts the existence of multiple ontologies of it as a political problem. Whereas the 'multiplicity of global climate problems' at issue suggests that climate change can be enacted or performed in multiple, oftentimes conflictual ways based on different ontologies, the PCM17's apocalyptic narrative of climate change overlooked the various assemblages of political practice that enact climate change differently. ${ }^{121}$ At the level of enactment, the conception of climate change in the PCM17 consisted of a universal, all-encompassing problem the likes of which a broken politics is no match for. On the one hand, demonstrators decried capitalism as fundamentally incompatible with effective management of climate change, instead aiming to 'stop capitalist pollution with socialist revolution'. ${ }^{122}$ On the other, they pointed to a corrupt and

\footnotetext{
${ }^{116}$ Mike Davis, Ecology of Fear: Los Angeles and the Imagination of Disaster (New York: Vintage Books, 1999); Adler, 'Peoples Climate March Hits D.C.'.

117 Swyngedouw, 'Apocalypse Forever?'.

118 Eman Mohammed, 'Climate March', Flickr, 29 April 2017. Available

at: https://www.flickr.com/photos/peoplesclimatemarch/34193099582/in/album-72157683199634655/. Last accessed April 3, 2019; Eman Mohammed, 'Climate March', Flickr, 29 April 2017. Available at: https://www.flickr.com/photos/peoplesclimatemarch/34220592371/in/album-72157683199634655/. Last accessed April 3, 2019; Meditch, 'Washington DC People's Climate March Photos'.

119 Swyngedouw, 'Apocalypse Forever?', 219.

${ }^{120}$ Nico Stehr and Amanda Machin, 'Trusting the Climate: Catastrophe vs. Stability', Society 53, no. 6 (2016): 573.

${ }^{121}$ Samuel Randalls, 'Climatic Globalities: Assembling the Problems of Global Climate Change', in The Politics of Globality since 1945: Assembling the Planet, eds. Rens van Munster and Casper Sylvest (London: Routledge, 2016), 145; Mol, 'Ontological Politics'.

${ }^{122}$ Fred Goldstein, 'Trump, the Ruling Class and the Paris Accords', Workers World, 7 June 2017. Available at: https://www.workers.org/2017/06/07/trump-the-ruling-class-and-the-paris-accords/. Last accessed April 3, 2019.
} 
broken political system infiltrated by oil executives whose actions would only worsen the crisis of climate change. ${ }^{123}$ These two conceptions of climate change as a political problem represented two sides of the same coin, as the causes of climate change were reduced to a single, discernible phenomenon, even while climate change itself remained a nightmare of all-encompassing proportion.

\section{Conclusions: For a Conflictual, Multiple and Radical Democratic Climate Change Politics} This article analysed the PCM17's logic of resistance through the perspective of agonism. It argued that an agonistic framework of analysis lends insight into the assumptions the PCM17 made about the nature of the political and of climate change. Specifically, an agonistic framework shows how the PCM17 conceived of the political as grounded in consensus and how it conceived of climate change as a singular problem. These features of the PCM17's logic of resistance were symptomatic of its role in depoliticising climate change. By contrast, embracing conflict as constitutive of the political and conceptualising climate change as multiple enacts a logic of resistance that opposes hegemony and embraces dissent, but does not surrender the responsibility to acknowledge the existence of climate change and address it in politics.

By understanding that conflict inaugurates the political, a logic of resistance follows that sanctions dissent in a radical democratic climate change politics. In principle, espousing the potentially constructive role of conflict in the politics of climate change would affirm novel forms of political subjectivity rather than begrudge and stifle them. As Machin observes, radical democracy extols the virtues of oppositional relations of political identities but is careful not to endorse violence. ${ }^{124}$ Furthermore, Machin's 'agonistic green citizenship' outlines how, in practice, a conflictual conception of the political could transform responsibility into a duty to uphold 'the irreducible disagreement arising from differently embodied citizens'. ${ }^{125}$ Enacting a radical democratic climate change politics through activism, then, would authorise activists as legitimate actors not in spite of the dissenting opinions within and between them, but because of them and their ability to craft avenues through which new and creative expressions of political identity could relate to one another in their resistance against hegemony. ${ }^{126}$ In other words, forming a concept of the political grounded in conflict offers the potential for a radical democratic politics of climate change that makes room for dissent in its logic of resistance.

Furthermore, considering climate change as a contested representation of multiple political ecologies offers the opportunity to transcend singular narratives of climate change and resist their hegemonising pressures without acquiescing to claims that climate change does not exist. Theorising climate change as multiple in this way would begin with emphasising the radical interconnectedness of humans and nature. ${ }^{127}$ However, it would also entail scrutinising singular narratives of climate change that portend a 'new, universal planetary globality'. ${ }^{128}$ This implies

\footnotetext{
${ }^{123}$ Meditch, 'Washington DC People's Climate March Photos'.

${ }^{124}$ Machin, Negotiating Climate Change, 116.

${ }^{125}$ Machin, 'Decisions, Disagreement and Responsibility', 847.

${ }^{126}$ Fougère and Bond, 'Legitimising Activism in Democracy'.

${ }^{127}$ This is one area where substantial progress has been made by, e.g. Randalls and Machin. See Randalls, 'Climatic Globalities'; Samuel Randalls, 'Climate Change Multiple', in Governing the Climate: New Approaches to Rationality, Power and Politics, eds. Johannes Stripple and Harriet Bulkeley (Cambridge: Cambridge University Press, 2013), 235-242; Machin, Negotiating Climate Change, 110-16.

${ }^{128}$ Randalls, 'Climatic Globalities', 160.
} 
that a radical democratic politics of climate change would support multiple political ecologies in describing precisely how humans relate to nature - here, specifically, to climate change - from a 'differentiated, localized perspective'. ${ }^{129}$ Crucially, this would not imply that climate change does not exist, only that it does not exist as singular. A robust logic of resistance in climate change activism thus begins with a conception of the political as conflictual and a conception of climate change as multiple, both of which together would support a radical democratic politics of climate change and a logic of resistance within it that could accommodate dissent and acknowledge that climate change exists.

\section{Acknowledgements}

I am deeply thankful for the thoughtful comments of Adam Goldstein, Karl Vika, Jack Stuart and Celia Lohr on previous versions of this article. I am also indebted to the anonymous reviewers, whose insights helped improve this article substantially.

\section{Funding}

This research received no specific grant from any funding agency in the public, commercial, or not-for-profit sectors.

\footnotetext{
${ }^{129}$ Machin, Negotiating Climate Change, 90.
} 